\title{
IMPLEMENTATION OF A LIMITED SET OF SSR MARKERS FOR SCREENING OF GENETIC VARIABILITY IN LATVIAN AND SWEDISH SOUR CHERRY (Prunus cerasus L.) GENETIC RESOURCES COLLECTIONS
}

\author{
Gunārs Lācis*, Isaak Rashal ${ }^{\star *}$, and Viktor Trajkovski ${ }^{\star \star \star}$ \\ * Latvia State Institute of Fruit-Growing, Graudu iela 1, Dobele, LV-3701, LATVIA, \\ e-mail: gunars.lacis@Ivai.Iv \\ ** Institute of Biology, University of Latvia, Miera iela 3, Salaspils, LV-2169, LATVIA \\ *** Swedish Pomological Science Centre, Stubbaröd 2818, SE 26023 Kågeröd, SWEDEN
}

Contributed by Isaak Rashal

\begin{abstract}
Forty-one sour cherry (Prunus cerasus L.) accessions were evaluated using three SSR markers to characterise genetic diversity in the sour cherry genetic resource collections at the Latvia State Institute of Fruit-Growing (LIFG), Dobele, Latvia and the Division of Horticultural Genetics and Plant Breeding at Balsgård, Department of Crop Sciences, Swedish University of Agricultural Sciences (SLU-Balsgård), Sweden, and to test the usability and reliability of a small set of SSR markers for preliminary characterisation of sour cherry germplasm collections. The SSR loci were highly polymorphic with 7-14 alleles per locus. Heterozygosity and Polymorphic Information Content values ranged from 0.750 to 1.000 and $0.748-0.899$, respectively, while discrimination power per locus varied from 0.716 to 0.965 . Five to thirty genotypes were found in the sour cherry collections for the three tested SSR loci. The combined discrimination power of all loci was effectively 0.994 and 0.999 for the LIFG and SLU-Balsgard collections, respectively. The SSRs used were able to uniquely identify all accessions in the analysed genetic resources collections. The genotype data allowed estimation of genetic diversity and genetic characterisation of accessions in the collections. Genetic similarity analysis showed higher genetic similarity among the Baltic and Scandinavian sour cherry varieties, than between Baltic and Eastern European varieties.
\end{abstract}

Key words: genetic diversity, germplasm, Prunus cerasus L., SSR.

\section{INTRODUCTION}

Sour cherry Prunus cerasus L. $(2 \mathrm{n}=4 \mathrm{x}=32)$ is an allotetraploid species, shown by comparative research on morphological, isozyme, and chloroplast RFLP homology of sour cherries and their proposed progenitor species: sweet cherries $(P$. avium $\mathrm{L}$; $2 \mathrm{n}=2 \mathrm{x}=16)$ and ground cherries $(P$. fruticosa Pail.; $2 \mathrm{n}=4 \mathrm{x}=32$ ) (Iezzoni, 2008). European sour cherries have a wide range of variability for different plant habit and fruit characters (Krahl et al., 1991; Beaver et al., 1995; Trajkovski, 1996).

Neither Latvia nor Sweden are leaders in sour cherry growing, but nevertheless it is a traditional crop in both countries and is grown in home gardens and has a high potential for industrial processing. For that reason both countries have long-term activities and experience in the collection, characterisation and evaluation of sour cherry genetic resources, and in the breeding of the species. The Latvia State Institute of Fruit-Growing (LIFG), and the Department of Crop Sci- ence of the Swedish University of Agriculture, Balsgård (SLU-Balsgård) hold valuable genetic resource collections of sour cherries, which are used for both research and breeding (Trajkovski, 1996; Rashal and Lacis, 1999). Both collections contain germplasm from western and eastern sour cherry types designated by Kolesnikova (Колесникова, 1975), as well as hybrid material developed from these types in the Swedish collection. Focused breeding work on sour cherries has been conducted in Sweden with the introduction of a wide range of genetic material from the entire northern hemisphere and through hybridisation and selection of new material (Trajkovski, 1996). The sour cherry germplasm collection at the SLU-Balsgård was developed to support the long established Swedish breeding programme. Therefore, the Swedish collection was built through collaboration with plant breeders in the entire northern temperate zone. Besides local (Scandinavian) material, the collection also includes introduced advanced cultivars from Western Europe and North America and a 
wide diversity of selections developed at Balsgård (Trajkovski, 1996). In contrast, the sour cherry collection at the LIFG consists mostly of locally grown landraces collected within Latvia, as well as introduced varieties tested for suitability for commercial growing.

Reports of genetic diversity and identity evaluation studies for sour cherry are comparatively fewer than for sweet cherry. Genetic studies on sour cherries have included the use of isozyme markers (Beaver et al., 1995), RFLPs (Wang et al., 1998), RAPDs (Cai et al., 2007), AFLPs (Tavaud et al., 2004), and SSR (Cantini et al., 2001; Canli, 2004; Pedersen, 2006). The use of SSR markers in the description of genetic resources has several advantages over other molecular markers: they are abundant in most genomes, uniformly distributed, multi-allelic and co-dominant. Therefore, SSRs have become the marker of choice for many plant species. SSR markers are PCR-based, thus requiring only a small amount of DNA for genotyping. Every SSR locus is defined by a unique pair of primers, thereby facilitating information exchange between laboratories and allowing individuals to be uniquely genotyped with a limited number of markers (Powell et al., 1996; Aranzana et al., 2003).

There is a clear necessity to expand genetic characterisation of sour cherries, as this information can be useful in breeding and genetic resources management. Previous studies have shown that preliminary analysis of sweet cherry genetic material can be successfully performed using a small number of SSR markers (Bianchi et al., 2004; Lacis et al., 2009a). Therefore, only three SSR markers PceGA25, PMS3 and PMS49 were chosen for characterisation of sour cherry collections, due to the very high level of polymorphism found in cherries (Cantini et al., 2001; Kacar et al., 2005; Pedersen, 2006). The goals of the present study were to test the usability and reliability of a small set of microsatellite (SSR) markers for preliminary characterisation of sour cherry germplasm collections and to undertake an initial genetic description of Latvian and Swedish sour cherry genetic resource collections.

\section{MATERIAL AND METHODS}

Plant material. Accessions from sour cherry genetic resource collections at the Latvia State Institute of FruitGrowing (LIFG) (nine accessions) and the Division of Horticultural Genetics and Plant Breeding at Balsgård, Department of Crop Sciences, Swedish University of Agricultural Sciences (SLU-Balsgård) (32 accessions) were genotyped (Table 1).

Isolation of genomic DNA. Young leaves were collected in both locations during May - June. Total DNA was isolated using a modified CTAB (hexadecyltrimethylammonium bromide) method (Nybom and Schaal, 1990). The leaves were ground to a fine powder in liquid nitrogen, and the DNA was extracted with $7 \mathrm{ml} 2 \%$ CTAB extraction buffer (2\% CTAB, $0.7 \mathrm{M} \mathrm{NaCl}, 50 \mathrm{mM}$ Tris, pH 8.9, $10 \mathrm{mM}$
EDTA, 0.1\% 2-mercaptoethanol) for 1 hour at $60{ }^{\circ} \mathrm{C}$. Further DNA isolation was continued according to the published method (Nybom and Schaal, 1990).

PCR analysis. Approximately 50 ng of genomic DNA was used for PCR amplification in a $25 \mu$ reaction containing $1 \mathrm{x}$ PCR reaction buffer, $2.5 \mathrm{mM} \mathrm{MgCl}_{2}, 0.2 \mathrm{mM}$ dNTPs, 2.5 pmol of each primer and 0.6 U Taq DNA polymerase (Fermentas, Lithuania). PCR reactions were run in an Eppendorf Mastercycler epgradient thermal cycler (Eppendorf, Germany) with one cycle of $3 \mathrm{~min}$ at $94{ }^{\circ} \mathrm{C}, 35$ cycles of $30 \mathrm{~s}$ at $94{ }^{\circ} \mathrm{C}, 30 \mathrm{~s}$ at $55^{\circ} \mathrm{C}$ and $90 \mathrm{~s}$ at $72{ }^{\circ} \mathrm{C}$, and one cycle of $5 \mathrm{~min}$ at $72{ }^{\circ} \mathrm{C}$ (Cantini et al., 2001). Genotyping was performed using the markers PceGA25, PMS3, PMS49 (Cantini et al., 2001).

PCR products were initially checked on $1 \%$ agarose gels in $1 \mathrm{x}$ TAE buffer and visualised by staining with ethidium bromide. The same PCR products were subsequently analysed on an ABI PRISM® 3100 Genetic Analyzer (Applied Biosystems, USA) using GeneMapper® Software v4.0 (Applied Biosystems, USA).

Data analysis. Heterozygosity was calculated according to the method of Weir (1990). The polymorphic information content (PIC) was calculated according to Röder et al. (1995). The probability of matching genotypes and their discriminating power were estimated according to Jones (1972) and Kloosterman et al. (1993). Pair-wise similarity of accessions was calculated using the Nei and Li similarity index (Nei and Li, 1979). The calculations were conducted using the computer programme 'SSRs' written by W.F. Lamboy (personal communication), which allows analysis of tetraploid species. For further analysis, the SSR fragments were coded as present (1) or absent (0) in a binary matrix, which was analysed using FreeTree v. 0.9.1.50 software (Hampl et al., 2001). Genetic distances were calculated using the Nei and Li/Dice similarity index (Nei and $\mathrm{Li}, 1979$ ) and cluster analysis was performed using the Neighbor-Joining method. The dendrogram was visualised with TreeView software v. 1.6.6. (Page, 1996) and MEGA v. 4 (Tamura et al., 2007). The structure of relationships among cultivars was validated by bootstrapping analysis, using FreeTree v. 0.9.1.50 software (Hampl et al., 2001).

\section{RESULTS}

The three primer pairs generated SSR fragments for all 41 accessions of the LIFG and SLU-Balsgård collections (Table 1), with 7 to 14 putative alleles identified per marker (Table 2). For all three markers, the number of alleles was higher in sour cherry accessions of the SLU-Balsgård collection. In the LIFG collection, the highest number of putative alleles (10) was found with the marker PMS49, whereas in the SLU-Balsgård collection the highest number of putative alleles (14 putative alleles) was identified with the marker PMS49. The lowest number of alleles in both sour cherry collections was found with the marker PceGA25. All putative alleles detected with the markers PMS3 and PMS49 
PUTATIVE ALLELES IDENTIFIED IN ACCESSIONS OF THE LATVIA STATE INSTITUTE OF FRUIT-GROWING (LIFG) AND THE DIVISION OF HORTICULTURAL GENETICS AND PLANT BREEDING AT BALSGÅRD, DEPARTMENT OF CROP SCIENCES, SWEDISH UNIVERSITY OF AGRICULTURAL SCIENCES (SLU-BALSGÅRD) SOUR CHERRY COLLECTION USING THREE SSR PRIMER PAIRS

\begin{tabular}{|c|c|c|c|c|c|c|c|c|}
\hline \multirow[t]{2}{*}{ No. } & \multirow[t]{2}{*}{ Accession name } & \multirow[t]{2}{*}{ Collection $*$} & \multirow{2}{*}{$\begin{array}{l}\text { Country of } \\
\text { origin }\end{array}$} & \multirow{2}{*}{$\begin{array}{c}\text { Acces- } \\
\text { sion } \\
\text { type } * *\end{array}$} & \multirow[t]{2}{*}{ Pedigree } & \multicolumn{3}{|c|}{ Loci } \\
\hline & & & & & & PceGA25 & $P M S 3$ & PMS49 \\
\hline 1 & $0103 i$ & SW & Sweden & B & $\begin{array}{c}\text { Brysselska Bruna - open pollina- } \\
\text { tion }\end{array}$ & 165,190 & 179,193 & 154 \\
\hline 2 & $0104 \mathrm{i}$ & SW & Sweden & $\mathrm{B}$ & $\begin{array}{c}\text { Brysselska Bruna - open pollina- } \\
\text { tion }\end{array}$ & $165,173,186$ & $171,189,193,199$ & $87,92,154$ \\
\hline 3 & $0116 \mathrm{i}$ & SW & Sweden & $\mathrm{B}$ & $\begin{array}{c}\text { Brysselska Bruna - open pollina- } \\
\text { tion }\end{array}$ & 153,165 & $167,189,193$ & 87,92 \\
\hline 4 & $1223 \mathrm{i}$ & SW & Sweden & $\mathrm{B}$ & Skugmorell - free pollination & $161,173,178$ & $175,187,189$ & $124,132,144,154$ \\
\hline 5 & $3232 \mathrm{~K}$ & SW & Sweden & $\mathrm{B}$ & Heiman's Rubin x Körösi Meggy & 165,181 & $175,183,189$ & $113,118,132,154$ \\
\hline 6 & $3318 \mathrm{~K}$ & SW & Sweden & $\mathrm{B}$ & BPr 27008 x Tschernokorka & 167 & 177,189 & 132,154 \\
\hline 7 & $3521 \mathrm{~B} 2$ & SW & Sweden & $\mathrm{B}$ & Körösi Meggy - open pollination & 165,173 & 171,183 & 70,75 \\
\hline 8 & $3540 \mathrm{~K}$ & SW & Sweden & $\mathrm{B}$ & $\begin{array}{c}\text { Griotte Kirschelinsky x } \\
\text { Skugmorell }\end{array}$ & 153,161 & 179,199 & $87,92,154$ \\
\hline 9 & $3643 \mathrm{~K}$ & SW & Sweden & $\mathrm{B}$ & Skugmorell x Heiman's Rubin & 167 & 183,193 & 134,154 \\
\hline 10 & $3882 \mathrm{~K}$ & SW & Sweden & $\mathrm{B}$ & BPr 27804 x Heiman’s Rubin & 165 & $171,179,189,201$ & $124,132,154$ \\
\hline 11 & Almaz & SW & Russia & A & $\begin{array}{c}\text { (Padocerasus M x Novoselka) x } \\
\text { Pamjatj Vavilova }\end{array}$ & 161,178 & $171,177,179,189$ & 75,154 \\
\hline 12 & BPr 32011 & SW & Sweden & $\mathrm{B}$ & Fanal x Skugmorell & 161,178 & 175,187 & $124,132,144,154$ \\
\hline 13 & BPr 32216 & SW & Sweden & $\mathrm{B}$ & Schyrpotrep x Ostheimer & 170,186 & $179,189,199$ & $124,132,154$ \\
\hline 14 & BPr 34201 & SW & Sweden & $\mathrm{B}$ & BPr 27008 - open pollination & 178 & $158,179,189,199$ & 70,75 \\
\hline 15 & BPr 34202 & SW & Sweden & $\mathrm{B}$ & BPr 27008 - open pollination & $161,173,181$ & $177,183,199,201$ & 87,92 \\
\hline 16 & Bulatnikovskaya & LV & Russia & A & Unknown & 161,175 & 183,199 & $75,78,154$ \\
\hline 17 & Cerella & SW & unknown & A & Unknown & 181 & $158,177,193$ & $124,132,154$ \\
\hline 18 & Heimans Rubin & SW & unknown & $\mathrm{L}$ & Unknown & $153,165,167$ & $175,189,193$ & $124,132,154$ \\
\hline 19 & Jonisku & LV & Lithuania & $\mathrm{L}$ & Unknown & 161,175 & $179,187,199$ & 132,154 \\
\hline 20 & Kirsa & LV/SW & Sweden & A & $\begin{array}{l}\text { Brysselska Bruna x Heiman's Ru- } \\
\text { bin }\end{array}$ & 165,173 & 167,193 & $87,92,132$ \\
\hline 21 & Körösi Meggy & SW & Hungary & A & Unknown & 165,178 & 179 & 75,118 \\
\hline 22 & Latvijas Augstais & $\mathrm{LV}$ & Latvia & $\mathrm{L}$ & Unknown & 161,178 & $179,187,205$ & $70,75,132$ \\
\hline 23 & Latvijas Zemais 3 & $\mathrm{LV}$ & Latvia & $\mathrm{L}$ & Unknown & 161,173 & $179,187,199$ & $70,75,87,92$ \\
\hline 24 & Laucienas & LV & Latvia & $\mathrm{L}$ & Unknown & 161,173 & $179,187,189$ & 87,92 \\
\hline 25 & Ljubskaya & $\mathrm{LV} / \mathrm{SW}$ & Russia & A & Unknown & 165 & 177,201 & 113,134 \\
\hline 26 & Meteor & SW & USA & A & $\begin{array}{l}\text { Montmorency x Russischer } \\
\text { Sämling }\end{array}$ & 178,190 & 171,187 & $70,75,116,113$ \\
\hline 27 & Montmorency & SW & unknown & $\mathrm{L}$ & Unknown & 165,178 & $171,199,205$ & $87,92,154$ \\
\hline 28 & Nefris & SW & Poland & A & Clone of Fanal & 167,178 & $175,189,193$ & $75,92,154$ \\
\hline 29 & Nordia & LV/SW & Sweden & A & Tschernokorka x BPr 24179 & 173,186 & $171,189,205$ & 128,154 \\
\hline 30 & Oblachinska & $\mathrm{LV} / \mathrm{SW}$ & Balcans & $\mathrm{L}$ & Unknown & 161,173 & 179,189 & $70,75,132,124$ \\
\hline 31 & Ostheimer & SW & unknown & $\mathrm{L}$ & Unknown & 170 & $171,189,199$ & $70,75,116$ \\
\hline 32 & Pamjatj Vavilova & SW & Russia & A & Unknown & $173,186,195$ & 187,189 & $70,75,128,132$ \\
\hline 33 & Pandy 8 & SW & Hungary & A & Unknown & 161,181 & 177,183 & $75,78,113,118$ \\
\hline 34 & Rubin & SW & Russia & A & Unknown & $165,178,190$ & $179,187,199$ & 132,154 \\
\hline 35 & Skuggmorell & SW & Sweden & $\mathrm{L}$ & Unknown & 161,173 & $179,187,199$ & $124,132,144,154$ \\
\hline 36 & Stevnsbær & SW & Denmark & $\mathrm{L}$ & Unknown & 163 & $175,179,187$ & $70,75,124,132$ \\
\hline 37 & Stora Klarbär & SW & Sweden & $\mathrm{L}$ & Unknown & 163,186 & $171,179,189,199$ & $87,92,154$ \\
\hline 38 & Studencheskaya & SW & Russia & A & Unknown & $165,181,195$ & $167,179,187,189$ & 132,154 \\
\hline 39 & $\begin{array}{l}\text { Surkörsbar från } \\
\text { H.Björkman }\end{array}$ & SW & Sweden & $\mathrm{L}$ & Unknown & 161,178 & $179,187,205$ & $70,75,124,132$ \\
\hline 40 & Svites & $\mathrm{LV}$ & Latvia & $\mathrm{L}$ & Unknown & 161,173 & $179,187,189$ & $75,87,92$ \\
\hline 41 & Tamaris & LV & Russia & A & Unknown & 161,195 & 167,187 & $70,75,128,134$ \\
\hline
\end{tabular}

* LV - sour cherry collection of the LIFG, SW - sour cherry collection of the SLU-Balsgård

** A - advanced cultivar, $\mathrm{B}$ - breeding line, $\mathrm{L}$ - landrace 
GENOTYPING RESULTS OF THE SOUR CHERRY ACCESSIONS IN THE LATVIA STATE INSTITUTE OF FRUIT-GROWING (LIFG) AND DIVISION OF HORTICULTURAL GENETICS AND PLANT BREEDING AT BALSGÅD OF THE DEPARTMENT OF CROP SCIENCES, SWEDISH UNIVERSITY OF AGRICULTURAL SCIENCES (SLU-BALSGÅRD) OBTAINED USING THREE SSR PRIMER PAIRS

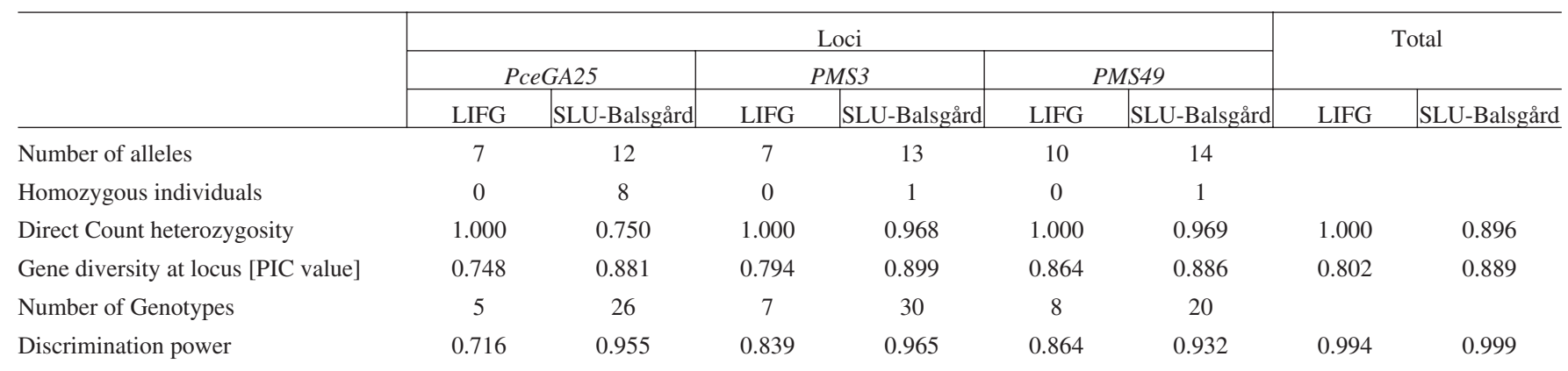

in the accessions of the LIFG collection were also found in the SLU-Balsgård accessions. For the marker PceGA25, the putative allele 175 was found in the LIFG sour cherry collection, but not in the SLU-Balsgård collection. Since the size difference between this allele and alleles 173 and 178 was two or more base pairs, it was considered as a unique allele.

Heterozygosity calculated by direct counts for the putative loci, identified by each marker, ranged from 0.750 to 1.000 with a mean value of 0.944 . The highest possible level of heterozygosity (1.000) was found in the LIFG sour cherry collection, but high values were found also in the SLU-Balsgård collection (0.750-0.969). The Polymorphic Information Content (PIC value) ranged from 0.748 to 0.899 with a mean value of 0.845 . The PIC values of all tested loci were generally lower for the LIFG collection (0.748, 0794 and 0.864 for PceGA25, PMS3 and PMS49, respectively) than for the SLU-Balsgård collection (0.881, 0.889 and 0.886 for PceGA25, PMS3 and PMS49, respectively). The total discrimination power of the tested markers was very high - 0.994 and 0.999 for the LIFG and SLU-Balsgård collections, respectively. Values of discrimi- nation power revealed that the most informative locus was PMS3 (0.965) for the SLU-Balsgård collection and PMS49 (0.864) for the LIFG collection (Table 2). The frequencies of detected putative allele ranged from 0.017 to 0.198 with a mean value of 0.0751. All three tested markers showed similar mean values of allele frequencies, 0.0770 (PceGA25), 0.0771 (PMS3) and 0.0714 (PMS49). All tested loci showed a high number of rare alleles with frequencies below 0.05 (Fig. 1). Fifty-three percent of the putative alleles identified in the sour cherry accessions had frequencies below 0.05 at PceGA25 locus, 50\% locus PMS49 and $31 \%$ at locus PMS3 (Fig. 1).

No accessions had the same allele profile for all three loci. Locus PceGA25 recorded 22 unique genotypes (53.7\% of total number of genotypes), locus $P M S 3-31$ unique genotypes $(75.5 \%)$ and PMS49 - 20 unique genotypes (48.8\%). A maximum of four alleles per locus were found in the sour cherry genotypes, as expected for tetraploid species. Only one allele was found in $17.1 \%$ of genotypes for locus $P M S 3$, in $29.3 \%$ of genotypes for locus PMS49 and none for locus PceGA25. Two alleles per locus were found in $17.1 \%, 46.3 \%$ and $26.8 \%$ of genotypes for loci PceGA25,

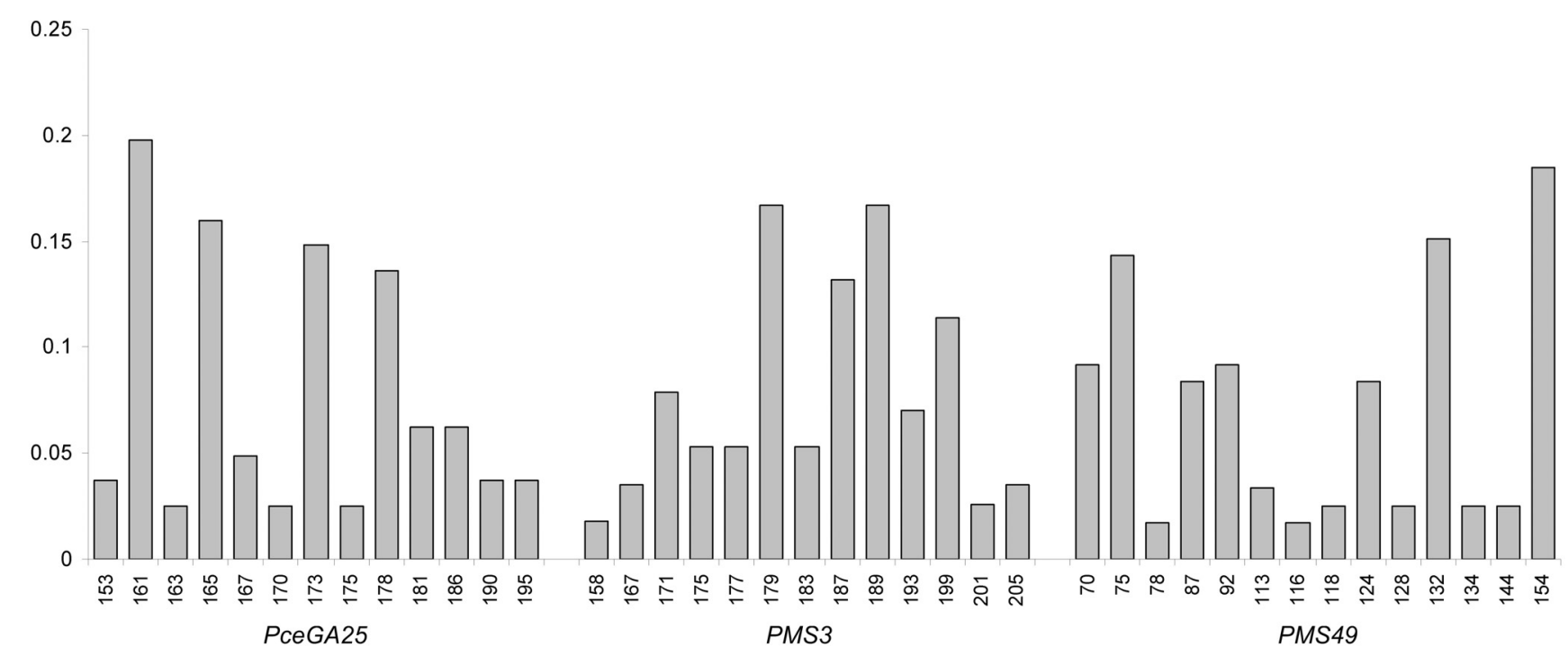

Fig. 1. Frequencies of putative alleles identified in two sour cherry collections using three SSR loci. 
PMS3 and PMS49, respectively. Similarly, three alleles per locus were found in $63.4 \%, 34.2 \%$ and $41.5 \%$ of genotypes for loci PceGA25, PMS3 and PMS49, respectively. The maximum number of alleles per locus was found in $19.5 \%$ of genotypes for locus PceGA25 and in $2.4 \%$ of genotypes for loci PMS3 and PMS49.

A dendrogram based on the Nei and Li/Dice similarity index (Nei \& Li, 1979) distinguished four clear groups (Fig. 2). Cluster analysis did not show significant genetic differentiation between collections. Sour cherry accessions from the LIFG collection were located in the three clusters among the varieties from SLU-Balsgård sour cherry collection (Fig. 2).

\section{DISCUSSION}

The three tested SSR markers identified a high number of alleles, heterozygosity and PIC value in the LIFG and SLU-Balsgård sour cherry collections, which resulted in high discrimination power. The tested markers have previously identified a high number of alleles in other investigations. Our results $(13,13$ and 14 alleles for PceGA25, PMS3 and $P M S 49$, respectively) are similar to the number of alleles detected by Cantini and colleagues (2001) - 14, 16 and 15 alleles for PceGA25, PMS3 and PMS49, respectively. The slightly lower number of alleles detected in our work might be explained by the lower number of analysed sour cherry accessions (41 in our work, and 75 in the work of Cantini et al., 2001). However, Pedersen (2006) analysed 22 sour cherry cultivars represented by 38 accessions and detected a much larger number of alleles (21, 31 and 20 alleles for PceGA25, PMS3 and PMS49, respectively). The sour cherry germplasm, analysed by Pedersen (2006) includes five clones of cv. Stevnsbær, several accessions from the Aarslev (Denmark) breeding programme as well as varieties from Germany, Hungary, USA etc. Differences between both data sets are probably explained by the different germplasm and different SSR detection methods used: automated sequencer capillary electrophoresis (ASCE) in our work and polyacrylamide gel electrophoresis (PAGE) in Pedersen's (2006) study. PAGE usually detects a higher number of putative alleles, possibly due to manual scoring errors and potential variability overestimation (Lacis et al., 2009 b). Another reason might be the relatively narrow genetic base of the Swedish hybrid material that was highly represented in the SLU-Balsgård sour cherry collection. This material was developed within the breeding programme using a limited number of parental varieties.

The tested primer pairs identified a high mean value of heterozygosity in the LIFG and SLU-Balsgård sour cherry collections - 0.919. Lower heterozygosity levels using the same SSR markers were found in other investigations of sour cherries - mean value 0.875 (Cantini et al., 2001) and 0.747 (Pedersen, 2006) using the same SSR markers. Similar discrepancies were found also for PIC values. The mean PIC value for the three SSR markers in our work was 0.886 , while the mean PIC value detected for the three primers by

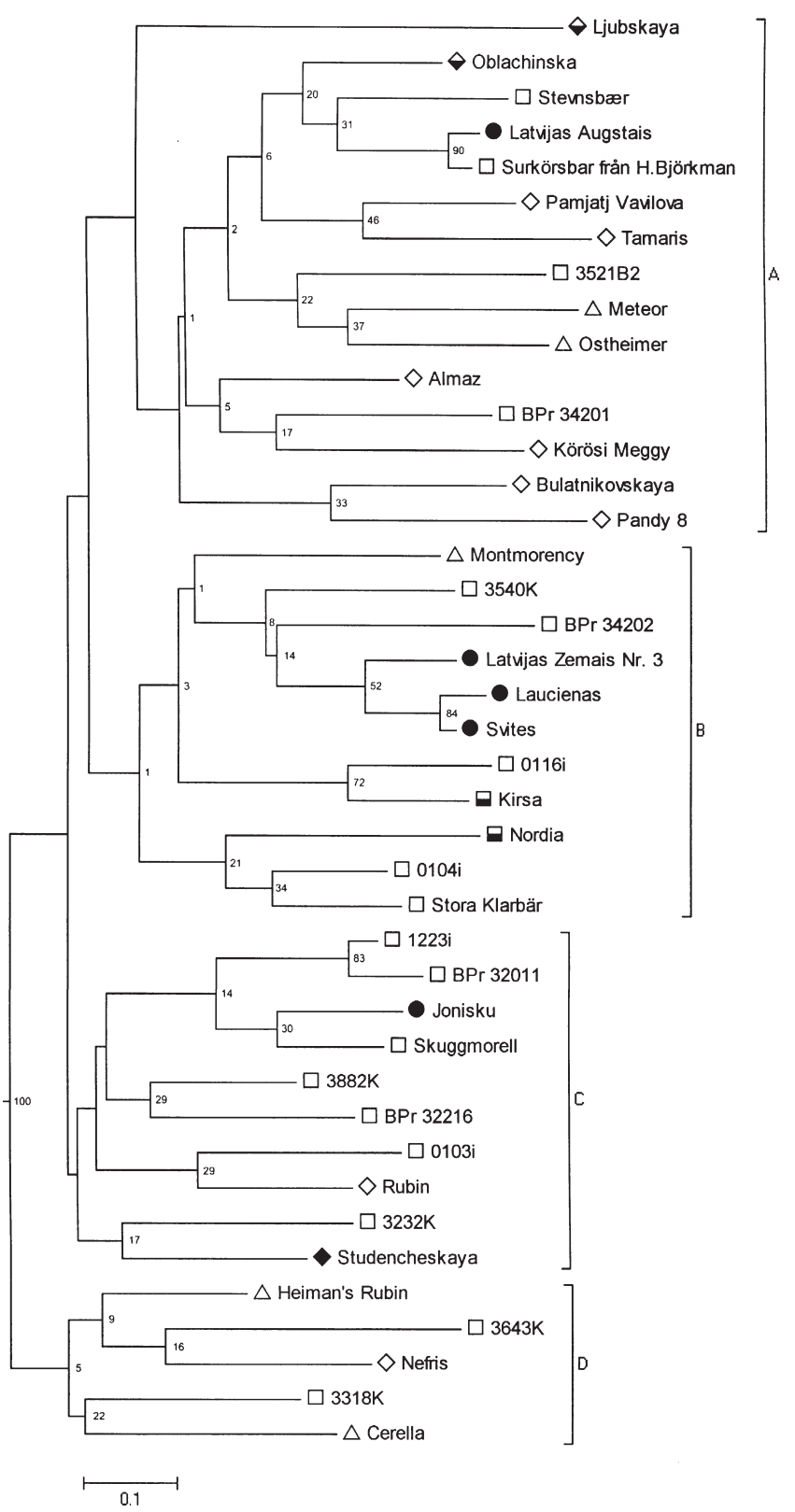

Fig. 2. Cluster analysis of accessions in the LIFG and SLU-Balsgård sour cherry collections using three SSR primer pairs based on the Nei and Li/Dice similarity index and the Neighbor-Joining clustering method.

Origin: $\bigcirc$ - Baltic, $\square$ - Nordic, $\diamond$ - Central European, $\triangle$ - other (incl. Western European, USA and unknown origin)

Empty symbols represent accessions of the SLU-Balsgård collection, filled ones - accessions of the LIFG collection, half-filled ones - accessions present in both collections.

Numbers indicate the percentage of bootstraps in which the branch was observed.

Cantini and colleagues (2001) was 0.865 and Pedersen (2006) - 0.947. Further, the total discrimination power of all three loci was 0.994 and 0.999 for the LIFG and SLU-Balsgård collections, while a value of $\sim 1.0$ was previously obtained using ten primer pairs (Cantini et al., 2001; Pedersen, 2006). The higher values of gene diversity and discrimination power for the SLU-Balsgård sour cherry col- 
lection, compared to the LIFG collection can be explained by the higher number of accessions in the former.

Putative allele number, loci heterozygosity and gene diversity per locus (PIC value) were similar for both the LIFG and SLU-Balsgård sour cherry collections (Table 2). For all genotyping parameters slightly higher values were recorded for the sour cherry accessions from the SLU-Balsgård collection. These differences can be explained by the different number of accessions in the collections: 9 and 32 for the LIFG and SLU-Balsgård, respectively.

The combination of three utilised polymorphic primer pairs allowed the differentiation of all of the 41 sour cherry accessions (Table 1). Four sour cherry cultivars (Kirsa, Ljubskaya, Nordia and Oblachinska) were present in both collections and had completely identical allele profiles. This confirmed the repeatability and transferability of the SSR analysis method, as accessions of the common sour cherry cultivars had the same origin - the accessions in the LIFG sour cherry collection were acquired from the SLUBalsgård collection.

The identified genotypes were compared with published results. Some discrepancies were found in accession identification, e.g. in our work the genotype of cv. Stevnsbær had a different putative allele profile for all three tested loci (163; $175,179,187 ; 70,75,124,132$, respectively for loci PceGA25, PMS3 and PMS49) than was found by Pedersen (2006) (Table 3). In our work only one putative allele 163 was found for locus PceGA25, which was also observed in cv. Stevnsbær c. Pernille by Pedersen (2006). Similar alleles with a fragment size shift of a few base pairs were also found in cv. Stevnsbær c. Birgitte (160), cv. Stevnsbær c. Lis (162), cv. Stevnsbær c. VS (161). Also, in the cv. Stevnsbær c. Pernille both alleles, 163 and 160, were found for locus PceGA25. In the cv. Stevnsbær clones analysed by B. Pedersen (2006) for locus PceGA25 several alleles were detected (143, 147, 156, 174 and 180) (Table 3) that were absent in our work. No identical putative alleles were found in our work with those found by B. Pedersen (2006) for locus PMS3. Similar alleles with few base pair shifts were found among cv. Stevnsbær c. Balsgård analysed in our work compared to other clones analysed by Pedersen (2006). Alleles over 200 bp in length (204, 205 and 206) were detected in all cv. Stevnsbær clones analysed by Pedersen (2006), but these were missing in our work. Our investigation discovered higher allele numbers and previ- ously undetected alleles for cv. Stevnsbær at the locus PMS49 (Table 3). Two clones of cv. Stevnsbær (c. VS and c. Viki) had the same allele 132 for PMS49 as in our investigation. Other alleles of locus PMS49 found in our investigation $(70,75$ and 124) were not found in any other cv. Stevnsbær clone.

Differences in the cultivar fingerprints can be due to several reasons. It is well known that the use of different SSR detection methods can cause differences in fragment sizing by one or a few base pairs (Lacis et al., 2009b). Since the sour cherry genotyping data used for comparison were acquired using different SSR detection methods (ASCE in the current paper and PAGE by Pedersen, 2006), this is the most probable reason for genotype differences between the data sets, especially in cases of one or few base pair size differences. The differences in the cultivar genotypes might also be explained by clonal differences within analysed cultivars from different collections, which is quite typical for widely grown landraces. Genetic differences among clones detected using SSR markers in the cv. Stevnsbær has been reported by Pedersen (2006).

Hierarchical Neighbor-Joining cluster analysis based on SSR genotyping data showed the relationships among sour cherry accessions in the LIFH and SLU-Balsgård collections (Fig. 2). No differential clustering of sour cherry accessions from the two different collections was found, probably because both sour cherry collections include accessions which represent a broad gene pool due to exchange of plant material between countries. Moreover both collections also contain common varieties as well as varieties of probable common origin, e.g. Russian and Central-European cultivars. The collection at SLU-Balsgård also contains hybrid material developed by crosses among geographically distant varieties. Although clear clustering according to geographical origin was not observed, most of the sour cherry accessions that originated in Russia and in the Central- and East-European countries are located in the Cluster A (Fig. 2). This cluster also contains the Scandinavian landraces Surkörsbar från H. Björkman and Stevnsbær, as well as the Latvian landrace Latvijas Augstais, which forms a compact closely related sub-group of accessions within Cluster A. Accessions from the LIFG sour cherry collection were distributed among varieties from the SLU-Balsgård collection, showing high relatedness among Baltic and Nordic sour cherry germplasm. A separate sub- group in Cluster B was

Table 3

GENOTYPES OF DIFFERENT CLONES OF SOUR CHERRY CULTIVAR STEVNSBÆR IDENTIFIED USING THREE SSR PRIMER PAIRS

\begin{tabular}{|c|c|c|c|c|}
\hline \multirow[t]{2}{*}{ Cultivar / clone } & \multicolumn{3}{|c|}{ Loci } & \multirow[t]{2}{*}{ Data source } \\
\hline & PceGA25 & $P M S 3$ & PMS49 & \\
\hline Stevnsbær c. Birgitte & 160,174 & $177,186,204$ & 135 & Pedersen, 2006 \\
\hline Stevnsbær c. Lis & 162 & $180,189,205$ & 136 & Pedersen, 2006 \\
\hline Stevnsbær c. Pernille & $147,160,163,180$ & $180,190,206$ & 136,156 & Pedersen, 2006 \\
\hline Stevnsbær c. Viki & 143 & $176,182,188,206$ & 132 & Pedersen, 2006 \\
\hline Stevnsbær c. VS & $143,147,156,161$ & $176,182,188,206$ & 132 & Pedersen, 2006 \\
\hline Stevnsbær c. SLU-Balsgård & 163 & $175,179,187$ & $70,75,124,132$ & Current work \\
\hline
\end{tabular}


identified for three related Latvian landraces (Latvijas Zemais Nr. 3, Laucienas and Svites) (Fig. 2).

Baltic (Latvian and Lithuanian) landraces included in the investigation showed close genetic relatedness with Scandinavian landraces, e.g. Latvian landrace Latvijas Augstais showed high relatedness with the Swedish landrace Surkörsbar från H. Björkman as well as with the Danish landrace Stevnsbær (Fig. 2). The Lithuanian landrace Jonisku showed high genetic relatedness with Swedish cv. Skuggmorell. These tendencies in the sour cherry genetic relatedness indicate the possible common historical origin of the Baltic and Scandinavian landraces. More clones of all the accessions should be included in further genetic analysis of these accessions to test for clonal variability within accessions.

The used molecular analysis approach was found to be useful for the preliminary characterisation of the sour cherry germplasm. The three highly polymorphic SSR loci utilised were able to uniquely identify all accessions in the analysed genetic resource collections. The applied SSR loci showed high discrimination power even for cultivar clones. Therefore, this SSR loci combination can provide fast and effective germplasm identification, genetic relatedness screening and germplasm management. For greater accuracy, especially for genetically similar germplasm, it would be necessary to increase the number of markers.

The number of different SSR alleles identified in the Latvian and Swedish sour cherry collections as well as population parameter characterisation, indicates that these collections contain a high level of genetic diversity and represent valuable material for breeding and research. Genetic similarity analysis showed higher genetic similarity between Baltic and Scandinavian sour cherry varieties, than between Baltic and Central and Eastern European (Hungarian, Polish and Russian) varieties.

\section{ACKNOWLEDGEMENTS}

This research was supported by the Swedish Research Council for Environment, Agricultural Sciences and Spatial Planning, the Royal Swedish Academy of Agriculture and Forestry, The Swedish Institute (SI), the Swedish Council for Forestry and Agricultural Research (SJFR) and the Knut and Alice Wallenberg Foundation.

\section{REFERENCES}

Aranzana, M.J., Pineda, A., Cosson, P., Dirlewanger, E., Ascasibar, J., Cipriani, G., Ryder, C.D., Testolin, R., Abbott, A., King, G.J., Iezzoni, A.F. \& Arus, P. (2003). A set of simple-sequence repeat (SSR) markers covering the Prunus genome. Theor. Appl. Genet., 106, 819-825.

Beaver, J. A., Iezzoni, A. F. \& Ramm, C. W. (1995). Isozyme diversity in sour, sweet, and ground cherry. Theor. Appl. Genet., 90, 847-852.

Bianchi, V.J., Sansavini S. \& Fachinello J.C. (2004). Microsatellite markers for identification of Prunus spp. rootstocks. Scientia Agricola, 61(3), 303-306.
Cai, Y.L., Cao, D.W. \& Zhao, G.F. (2007). Studies on genetic variation in cherry germplasm using RAPD analysis. Scientia Hort., 111, 248-254.

Canli, F.A. (2004). Development of a second generation genetic linkag map for sour cherry using SSR markers. Pakistan J. Biol. Sci., 7(10), 1676-1683.

Cantini, C., Iezzoni, A.F., Lamboy, W.F., Boritzki, M. \& Struss, D. (2001). DNA fingerprinting of tetraploid cherry germplasm using simple sequence repeats. J. Amer. Soc. Hort. Sci., 126, 205-209.

Hampl, V., Pavlicek, A. \& Flegr, J. (2001). Construction and bootstrap analysis of DNA fingerprinting-based phylogenetic trees with a freeware program FreeTree: Application to trichomonad parasites. Int. J. Syst. Evol. Microbiol., 51, 731-735.

Iezzoni, A.F. (2008). Cherries. In: J.F. Hancock (ed.). Temperate Fruit Crop Breeding: Germplasm to Genomics (pp. 151-175). Springer.

Jones, D.A. (1972). Blood samples: Probability of discrimination. J. Forensic Sci. Soc., 12, 355-359.

Kacar, Y.A., Iezzoni, A. \& Cetiner, S. (2005). Sweet cherry cultivar identification by using SSR markers. J. Biol. Sci., 5(5), 616-619.

Kloosterman, A.D., Budowle, B. \& Daselaar, P. (1993). PCR-amplication and detection of the human D1S80 VNTR locus. Int. J. Leg. Med., 105, 257-264.

Krahl, K.H., Lansari, A. \& Iezzoni, A.F. (1991). Morphological variation within a sour cherry collection. Euphytica, 52, 47-55.

Lacis, G., Rashal, I., Ruisa, S., Trajkovski, V. \& Iezzoni, A. F. (2009a). Assessment of genetic diversity of Latvian and Swedish sweet cherry (Prunus avium L.) genetic resources collections by using SSR (microsatellite) markers. Scientia Hort., 121, 451-457.

Lacis, G., Rashal, I. \& Trajkovski, V. (2009b). Comparative analysis of sweet cherry (P. avium) genetic diversity revealed by two methods of SSR marker detection. Proc. Latv. Acad. Sci., 4(3/4), 149-158.

Nei, M., Li W.H. (1979). Mathematical model for studying genetic variation in terms of restriction endonucleases. Proc. Natl. Acad. Sci. U.S.A., 76, 5269-5273.

Nybom, H., Schaal, B.A. (1990). DNA 'fingerprints' reveal genotypic distributions in natural populations of blackberries and raspberries (Rubus, Rosaceae). Amer. J. Bot., 44, 883-888.

Page, R.D.M. (1996). TREEVIEW: An application to display phylogenetic trees on personal computers. Comp. Appl. in Biosci., 12, 357-358.

Pedersen, B.H. (2006). DNA fingerprints of 51 sweet and sour Prunus accessions using Simple Sequence Repeats. J. Hort. Sci. \& Biotechnology, 81(1), 118-124.

Powell, W., Machray, G.C. \& Provan, J. (1996). Polymorphism revealed by simple sequence repeats. Trends Plant Sci., 1, 215-221.

Rashal, I., Lacis, G. (1999). Accessions of horticultural plants in the Latvian plant genetic resources data base. In: Ikase, L., Skrivele, M., Rasals, I., Ruisa, S., Trajkovski V. (eds.). Fruit Growing Today and Tomorrow. Collection of Scientific Articles, Dobele, pp. 124-130.

Röder, M.S., Plaschke, J., Konig, S.U., Bonier, A., Sorrells, M.E., Tanksley, S.D. \& Ganal, M. W. (1995). Abundance, variability and chromosomal location of microsatellites in wheat. Mol. Genet. Genom., 246, 327-333.

Tamura, K., Dudley, J., Nei, M. \& Kumar, S. (2007). MEGA4: Molecular Evolutionary Genetics Analysis (MEGA) software version 4.0. Mol. Biol. Evol., 24, 1596-1599.

Tavaud, M., Zanetto, A., David, J.L., Laigret, F. \& Dirlewanger, E. (2004). Genetic relationships between diploid and allotetraploid cherry species (Prunus avium, Prunus x gondouinii and Prunus cerasus). Heredity, 93, 631-638. 
Trajkovski, V. (1996). A review of the cherry breeding program in Sweden. Acta Hort., 410, 387-388.

Wang, D., Karle, R., Brettin, T. S. \& Iezzoni, A. F. (1998). Genetic linkage map in sour cherry using RFLP markers. Theor. Appl. Genet., 97, 1217-1224.

Received 28 February 2011
Weir, B.S. (1990). Genetic Data Analysis - Methods for Discrete Population Genetic Data. Sinauer Associates Inc. Publishers, Sunderland, MA, USA. 377 pp.

Колесникова А.Ф. (1975). Селекция и некоторые биологические особенности вишни в средней полосе РСФСР [Breeding and Some Biological Characteristics of Sour Cherry in Central Russia]. Орел: Отделение Приокского кн. изд.-ва. 328 с. (in Russian).

\section{IEROBEŽOTA SKAITA SSR MARKIIERU KOMPLEKTA PIELIETOŠANA LATVIJAS UN ZVIEDRIJAS SKĀBO KIRŠU (Prunus cerasus L.) ĢENĒTISKO RESURSU KOLEKCIJU ĢENĒTISKĀS DAUDZVEIDĪBAS IZVĒRTĒŠANĀ}

Četrdesmit viens skābo kiršu (Prunus cerasus L.) paraugs tika analizēts, izmantojot trīs SSR markiierus, lai raksturotu ǵenētisko daudzveidību divās skābo kiršu ğenētisko resursu kolekcijās: Latvijas Valsts aug̣̣kopības institūtā (LVAI), Dobelē un Zviedrijas Lauksaimniecības zinātnu universitātes Dārzkopības ǵenētikas un selekcijas nodaḷā Balsgård (SLU-Balsgård), kā arī lai pārbaudītu ierobežota skaita SSR marḳieru komplekta pielietojamību skābo kiršu ğenētisko resursu kolekciju raksturošanai. Lietotie SSR marḳieri nodrošināja visu skābo ķiršu paraugu identifikāciju, ko noteica marķieru augstā izšḳiršanas spēja: 0,994 (LVAI) un 0,999 (SLU-Balsgård). Pētìjumā tika konstatēts ḷoti augsts polimorfisma līmenis (7 līdz 14 alēles), līdz ar to arī heterozigotātes un gēnu polimorfisma vērtības bija augstas - attiecīgi no 0,750 līdz 1,000 un no 0,748 līdz 0,899. Kopumā pieci līdz trīsdesmit genotipi tika konstatēti pētāmajās skābo kiršu kolekcijās, izmantojot trīs SSR marḳierus. Pētījumā lietotais ierobežota skaita SSR markiieru komplekts nodrošināja skābo kiršu ǵenētisko resursu kolekcijas genotipēšanu un ǵenētiskās daudzveidības raksturojumu. Ģenētiskās līdzības analīze parādīja lielāku ġenētisko radniecību starp Baltijas un Skandināvijas skābo ķiř̌u paraugiem, nekā starp Baltijas un Austrumeiropas šķirnēm. 